This manuscript has already been published in the journal. Please refer to the following publication:

Dymecka, J., Gerymski, R., Machnik-Czerwik, A. (2021). How does stress affect our life satisfaction during COVID-19 pandemic? Moderating mediation analysis of sense of coherence and fear of coronavirus. Psychology, Health \& Medicine.DOI: $\underline{10.1080 / 13548506.2021 .1906436}$

\title{
How does stress affect life satisfaction during the COVID-19 pandemic? Moderated mediation analysis of sense coherence and fear of coronavirus
}

\author{
Joanna Dymecka, Rafał Gerymski, Anna Machnik-Czerwik
}

Department of Health Psychology and Quality of Life, Institute of Psychology, Opole University, Opole, Poland

\section{Author details \\ Joanna Dymecka \\ Dhttps//orcid.org/0000-0002-7092-3017 \\ Rafał Gerymski \\ (Dhttps//orcid.org/0000-0003-4847-1429 \\ Anna Machnik-Czerwik \\ Dhttps//orcid.org/0000-0002-0582-248X}

Correspondence concerning this article should be addressed to Rafał Gerymski, Staszica Square 1, Opole 45-015, Poland. Email: rafal.gerymski@ uni.opole.pl 


\section{How does stress affect life satisfaction during the COVID-19 pandemic? Moderated mediation analysis of sense of coherence and fear of coronavirus}

The aim of the present study was to determine the relationship between fear of COVID-19, stress, sense of coherence, and life satisfaction during the coronavirus pandemic. Participants were 907 Polish people (522 women and 385 men). We used the Perceived Stress Scale (PSS10), Fear of COVID-19 Scale (FOC-6), Sense of Coherence Scale (SOC-29) and the Satisfaction with Life Scale. The relationship between stress and life satisfaction was mediated by the sense of coherence, and the relationship between stress and sense of coherence was moderated by fear of COVID-19. The fear of COVID-19 acted as a buffer in the relationship between stress and sense of coherence weakening the impact of stress on the sense of coherence. This study is the first to verify the proposed model of moderated mediation during the COVID-19 pandemic and was undertaken in a very large sample. This manuscript highlights the important role of the fear of COVID-19 and sense of coherence in our well-being. An individual's sense of coherence can affect their subjective well-being and help them to effectively manage stress and reduce anxiety.

Keywords: COVID-19; fear of coronavirus; stress, sense of coherence; life satisfaction 


\section{Introduction}

The COVID-19 outbreak has caused widespread stress. Increasing numbers of confirmed cases and deaths, strict isolation measures and closures of schools and workplaces have been associated with significant levels of stress (Chen et al., 2020). A fear of COVID-19 is related to perceived stress (Dymecka, Gerymski, Machnik-Czerwik, 2021) and negatively affects mental health (Fardin, 2020; Su et al., 2007).

Infectious diseases trigger a wide range of emotional responses, but not everyone experiences the same fear or stress (Khalid et al., 2016). Individual characteristics enable a person to adapt efficiently to difficult circumstances (Bonanno, Rennicke, Dekel, 2005). One of these characteristics is a sense of coherence, defined as the degree of meaningfulness, comprehensibility, and manageability that people feel in their life (Antonovsky, 1987). Sense of coherence seems to be an important resource for dealing with pandemic stress. It is particularly necessary when strong stressors affect the individual (Dymecka, 2018). A strong sense of coherence is negatively associated with fear and perceived stress (Eriksson, Lindström, 2006).

Sense of coherence is also a health resource that affects the quality of life (Eriksson, Lindström, 2006; Floyd et al., 2011). It plays a mediating role in the relationships between various variables (Braun-Lewensohn, Sagy, Roth, 2011; Tang et al., 2013; Wiesmann, Dezutter, Hannich, 2014; Krok, 2016), including those between adverse experiences and psychological well-being (Gana, 2001), and between stress (and coping with it) and life satisfaction (Rohani et al, 2015). People with a strong sense of coherence can adapt to stress despite adversity and maintain good health and quality of life (Mc Gee et al., 2018). Therefore, it can be assumed that sense of coherence will be a mediator of the relationship between perceived stress, which may be exacerbated by a fear of COVID, and life satisfaction during a global pandemic (see Figure 1). 


\section{Materials and methods}

\section{Participants}

Study participants were 907 Polish people (522 women and 385 men). The average age of respondents was 39.28 years. Most of the respondents had secondary (38\%) or higher (51\%) education, lived in towns (45\%) and were professionally active (70\%). The study participants were part of the general population. Participant characteristics are detailed in Table 1.

[INSERT TABLE 1 ABOUT HERE]

\section{Procedure}

Recruitment of the study participants was carried out between March and May 2020 via the Internet using the snowball method. The participants were informed their responses would be anonymous. All respondents gave their informed consent to participate in this study, which was carried out in accordance with the guidelines of the University of Opole Bioethics Committee.

\section{Measures}

Perceived stress was measured using the Perceived Stress Scale (PSS-10; Cohen, Kamarck, Mermelstein, 1983) adapted by Juczyński and Ogińska-Bulik (2009), which consists of 10 questions on a five-point scale. The scale shows good reliability (Cronbach's $\alpha$ $=.78-.86$; in the present study Cronbach's $\alpha=.86$ ).

Fear of coronavirus was measured using the Fear of COVID-19 Scale (FOC-6; Dymecka, Gerymski, Machnik-Czerwik, 2021), a six-item questionnaire with responses on a five-point scale. The scale shows good reliability in its psychometric properties (in the present study Cronbach's $\alpha=.83$ ).

We also used the Sense of Coherence Scale (SOC-29; Antonovsky, 1993) adapted by Koniarek et al. (1993), which consists of 29 questions on a seven-point scale. Only the global 
score was used in this study. The scale shows good reliability (Cronbach's $\alpha=.74-.91$; in present study Cronbach's $\alpha=.91$ ).

The Satisfaction with Life Scale (Diener et al., 1985) adapted by Czapiński (2004) consists of five questions on a seven-point scale. The scale shows good reliability in its psychometric properties (Cronbach's $\alpha=.87$; in the present study Cronbach's $\alpha=.87$ ).

\section{Statistical analysis}

The significance of the relationships was tested with Pearson's $r$. Moderated mediation analysis was performed using PROCESS v3.4 (Hayes, 2017). Power analysis was conducted using G*Power 3.1.9.7 (Faul et al., 2020). A significance level of $\alpha=.05$ was adopted as the threshold value for statistical significance.

\section{Results}

\section{Correlation analysis}

Stress was positively correlated with fear of COVID-19. Stress and fear of COVID-19 were negatively associated with sense of coherence and life satisfaction. Sense of coherence was positively correlated with life satisfaction (Table 2).

\section{[INSERT TABLE 2 ABOUT HERE]}

\section{Moderated mediation analysis}

The bootstrap analysis (5000 samples; Preacher, Hayes, 2008) was used in PROCESS 3.4 Model 7 (Hayes, 2017). The results of the analysis are presented in Figure 2. 
The index of moderated mediation indicated that fear of COVID-19 moderated the indirect effect of the sense of coherence in the relationship between stress and life satisfaction. The results suggest that COVID-19 buffered the relationship between stress and sense of coherence, weakening the impact of stress on the sense of coherence (see Figure 3). The indirect effect of sense of coherence in the relationship between stress and life satisfaction was significant at all three levels of the moderator (see Table 3).

[INSERT TABLE 3 ABOUT HERE]

[INSERT FIGURE 3 ABOUT HERE]

\section{Power analysis}

For a small effect size $\left(f^{2}=.02\right)$ and a significance of $\alpha=.05$, the obtained sample was sufficient for a power of .96 .

\section{Discussion}

The present results show that in a situation of high stress (as during the pandemic), sense of coherence is higher in people with a strong fear of COVID-19. Previous studies have shown that severe isolation measures are associated with significant levels of stress in the general population (Chen et al., 2020; Lee et al., 2020; Polizzi, Lynn, Perry, 2020). It is likely that people with a weak fear of COVID-19 felt only the negative consequences of isolation and lack of freedom, whereas those with a strong fear of COVID-19 felt that isolation was reasonable. A feeling that restrictions are sensible can raise the level of meaningfulness, which increases the sense of coherence. Sullivan (1989) argued that a sense of coherence depends more on faith in the legitimacy and logic of a given event than on satisfying the needs of the individual. People with a strong fear of COVID-19 might also have a strong sense of coherence because following isolation rules brings clarity and order into their lives.

Several studies have shown that negative life events can reduce sense of coherence (Karlsson, Berglin, Larsson, 2000), particularly situations of uncertainty and risk of disease 
compared to explicit situations (Basińska, 2001), which includes pandemics. There is a view that people whose sense of coherence is already low or moderate are especially liable to its reduction under the influence of negative life events. In contrast, people with a strong sense of coherence are more resistant to negative changes (Hochwalder, Forsell, 2011) and negative life events do not reduce sense of coherence (Hochwalder, Forsell, 2011).

Sense of coherence in the present study was also a mediator of the relationship between stress and life satisfaction. This is in line with other studies showing that a sense of coherence was a mediator between chronic stress and life satisfaction (Mc Gee et al., 2018). A sense of coherence can be a source of resilience. Many studies have confirmed the relationship between sense of coherence and well-being (Bruscia et al., 2008). Sense of coherence makes us perceive a disease as less threatening (Gerasimčik-Pulko et al., 2009) and less stressful (Gustavsson-Lilius et al., 2007), and it can act as a protective factor against the harmful effects of perceived stress (Koushede et al, 2012; Koushede et al., 2011). A strong sense of coherence is particularly important when an individual experiences very difficult situations (Dymecka, 2018). Longitudinal studies indicate that sense of coherence can have a positive impact on the response to upcoming challenges over time, and improve quality of life (Rohani et al, 2015). The mediation path of the sense of coherence in the context of the present study seems to be the key to understanding how a stronger sense of coherence as an internal resource can serve as a protective factor in psychological adaptation to difficult life events.

\section{Limitations}

The tested moderated mediation model suggests causal relationships, but the moderated mediation analysis is only a complementary tool that does not allow cause and effect relationships to be determined. A longitudinal study should be carried out to verify the suggested relationships. In addition, our results are based on the Polish population. International research should be carried out to confirm the proposed model.

\section{Summary}

This study is the first to verify the proposed model of moderated mediation during the COVID-19 pandemic. Analyses were conducted in a very large sample and highlight the important roles of the fear of COVID-19 and the sense of coherence in our well-being. 
SENSE OF COHERENCE \& FEAR OF COVID-19

\section{Acknowledgments}

None.

\section{Declaration of interest}

Here are no relevant financial or non-financial competing interest to report. 


\section{References}

Antonovsky, A. (1987). Unraveling The Mystery of Health - How People Manage Stress and Stay Well. San Francisco: Jossey-Bass Publishers.

Antonovsky, A. (1993). The structure and properties of the sense of coherence scale. Social Science \& Medicine, 36(6), 725-733.

https:/doi.org/10.1016/0277-9536(93)90033-Z

Basińska, B. (2001). Radzenie sobie z konfrontacją stresową a kontinuum zdrowie - choroba nowotworowa [Coping with stress versus the health - cancer continuum]. Psychoonkologia/Psycho-oncology, 8, 25-33.

Bonanno, G. A., Rennicke, C., \& Dekel, S. (2005). Self-enhancement among high-exposure survivors of the September 11th terrorist attack: resilience or social maladjustment?. Journal of Personality and Social Psychology, 88(6), 984-998. https:/doi.org/10.1037/0022-3514.88.6.984

Braun-Lewensohn, O., Sagy, S., \& Roth, G. (2011). Brief report: adolescents under missile attacks: sense of coherence as a mediator between exposure and stress-related reactions. Journal of Adolescence, 34(1), 195-197.

https $/ /$ doi.org/10.1016/j.adolescence.2010.01

Bruscia, K., Shultis, C., Dennery, K., \& Dileo, C. (2008). The sense of coherence in hospitalized cardiac and cancer patients. Journal of Holistic Nursing, 26(4), 286-294. https $/ /$ doi.org/10.1177/0898010108317400

Chen, Q., Liang, M., Li, Y., Guo, J., Fei, D., Wang, L., He, L., Sheng, C., Cai, Y., Li, X., Wang, J., Zhang, Z. (2020). Mental health care for medical staff in China during the COVID-19 outbreak. The Lancet Psychiatry, 7(4), E15-E16.

https //doi.org/10.1016/S2215-0366(20)30078-X

Cohen, S. Kamarck, T., Mermelstein, R. (1983). A global measure of perceived stress. Journal of Health and Social Behavior, 24(4), 385-396. https:/doi.org/10.2307/2136404

Czapiński, J. (Ed). (2004). Psychologia pozytywna. [Positive psychology]. Warsaw: PWN.

Diener, E.D., Emmons, R.A., Larsen, R.J., Griffin, S. (1985).The satisfaction with life scale. Journal of Personality Assessment, 49(1), 71-75.

https://doi.org/10.1207/s15327752jpa4901_13 
Dymecka, J. (2018). Poczucie koherencji a style radzenia sobie ze stresem rodziców dzieci z chorobą nowotworową [Sense of coherence and coping styles in parents of children with cancer]. Psychoonkologia/Psycho-oncology, 22 (2), 41-49. https $/ /$ doi.org/10.5114/pson.2018.82618

Dymecka, J., Gerymski, R., Machnik-Czerwik, A. (2021). Fear of COVID-19 as a buffer in the relationship between perceived stress and life satisfaction in the Polish population at the beginning of the global pandemic. Health Psychology Report, 9(2), Online First. https $/ / 10.5114 /$ hpr.2020.102136

Eriksson, M., \& Lindström, B. (2006). Antonovsky's sense of coherence scale and the relation with health: a systematic review. Journal of Epidemiology and Community Health, 60(5), 376-381.

https:/doi.org/10.1136/jech.2005.041616

Fardin, M A. (2020). COVID-19 and Anxiety: A Review of Psychological Impacts of Infectious Disease Outbreaks, Archives of Clinical Infectious Diseases, Online ahead of Print; 15 (COVID-19):e102779.

https:/doi.org/10.5812/archcid.102779

Faul, F., Erdfelder, E., Buchner, A., Lang, A.-G. (2020). G*Power Version 3.1.9.7 [Computer software].Retrieved from: http://www.psychologie.hhu.de/arbeitsgruppen/allgemeinepsychologie-und-arbeitspsychologie/gpower.html

Floyd, A., Dedert, E., Ghate, S., Salmon, P., Weissbecker, I., Studts, J. L., Stetson, B., \& Sephton, S. E. (2011). Depression may mediate the relationship between sense of coherence and quality of life in lung cancer patients. Journal of Health Psychology, 16(2), 249-257.

https $/ /$ doi.org/10.1177/1359105310371856

Gana, K. (2001). Is sense of coherence a mediator between adversity and psychological wellbeing in adults? Stress and Health: Journal of the International Society for the Investigation of Stress, 17(2), 77-83.

https $/ /$ doi.org/10.1002/smi.882

Gerasimčik - Pulko, V., Pileckaitė - Markovienè, M., Bulotienė, G., Ostapenko, V. (2009). Relationship between sense of coherence and quality of life in early stage breast cancer patients. Acta Medica Lituanica, 16(3-4), 139-144.

https:/doi.org/10.2478/v10140-009-0020-X 
Gustavsson-Lilius, M., Julkunen, J., Keskivaara, P., \& Hietanen, P. (2007). Sense of coherence and distress in cancer patients and their partners. Psycho-oncology, 16(12), 1100-1110.

https:/doi.org/10.1002/pon.1173

Hayes, A. F. (2017). Introduction to mediation, moderation, and conditional process analysis: A regression-based approach. New York: Guilford Publications.

Hochwalder , J., Forsell, Y. (2011). Is Sense of Coherence Lowered by Negative Life Events?. Journal of Happiness Studies, 12, 475-492. https $/ /$ doi.org/10.1007/s10902-010-9211-0

Juczyński, Z., Ogińska-Bulik, N. (2009). Narzędzia pomiaru stresu i radzenia sobie zestresem [Tools for measuring stress and coping]. Warsaw: PTP.

Khalid, I., Khalid, T. J., Qabajah, M. R., Barnard, A. G., \& Qushmaq, I. A. (2016). Healthcare Workers Emotions, Perceived Stressors and Coping Strategies During a MERS-CoV Outbreak. Clinical Medicine \& Research, 14(1), 7-14. https:/doi.org/10.3121/cmr.2016.1303

Karlsson, I., Berglin, E., \& Larsson, P. A. (2000). Sense of coherence: quality of life before and after coronary artery bypass surgery--a longitudinal study. Journal of Advanced Nursing, 31(6),1383-1392.

\section{https:/doi.org/10.1046/j.1365-2648.2000.01408.x}

Koniarek, J., Dudek, B., Makowska, Z. (1993). Kwestionariusz orientacji życiowej. Adaptacja The Sense of Coherence Questionnaire (SOC) A. Antonovsky'ego. Przeglad Psychologiczny, 36(4), 491-502.

Koushede, V., Hansen, E. H., Andersen, A., \& Holstein, B. E. (2012). Young adults' medicine use for headache: the combined effect of socioeconomic position and perceived stress, and the contribution of sense of coherence. Research in Social \& Administrative Pharmacy, 8(6),533-541.

https:/doi.org/10.1016/j.sapharm.2012.01.007

Koushede, V., Holstein, B. E., Andersen, A., \& Hansen, E. H. (2011). Stress and medicine use for headache: does sense of coherence modify the association?. European Journal of PublicHealth, 21(5),656-661.

https:/doi.org/10.1093/eurpub/ckq077

Krok D. (2016). Sense of coherence mediates the relationship between the religious meaning system and coping styles in Polish older adults. Aging \& Mental Health, 20(10), 1002- 
1009. https:/doi.org/10.1080/13607863.2015.1056772

Lee, S. M., Kang, W. S., Cho, A. R., Kim, T., \& Park, J. K. (2018). Psychological impact of the 2015 MERS outbreak on hospital workers and quarantined hemodialysis patients. Comprehensive Psychiatry, 87, 123-127. https:/doi.org/10.1016/j.comppsych.2018.10.003

Mc Gee, S. L., Höltge, J., Maercker, A., \& Thoma, M. V. (2018). Sense of Coherence and Stress-Related Resilience: Investigating the Mediating and Moderating Mechanisms in the Development of Resilience Following Stress or Adversity. Frontiers in Psychiatry, 9,378. https $/ /$ doi.org/10.3389/fpsyt.2018.00378

Polizzi, C., Lynn, S.J., Perry, A. (2020). Stress and Coping in the Time of COVID-19: Pathways to Resilience and Recovery. Clinical Neuropsychiatry, 17 (2), 59-62. https $/ /$ doi.org/10.36131

Preacher, K. J., Hayes, A. F. (2008). Asymptotic and resampling strategies for assessing and comparing indirect effects in multiple mediator models. Behavior Research Methods, 40(3),879-891.

https:/doi.org/10.3758/BRM.40.3.879

Rohani, C., Abedi, H. A., Sundberg, K., \& Langius-Eklöf, A. (2015). Sense of coherence as a mediator of health-related quality of life dimensions in patients with breast cancer: a longitudinal study with prospective design. Health and Quality of Life Outcomes, 13, 195.

https:/doi.org/10.1186/s12955-015-0392-4

Rohani, C., Abedi, H. A., Omranipour, R., \& Langius-Eklöf, A. (2015). Health-related quality of life and the predictive role of sense of coherence, spirituality and religious coping in a sample of Iranian women with breast cancer: a prospective study with comparative design. Health and Quality of Life Outcomes, 13, 40. https:/doi.org/10.1186/s12955-015-0229-1

Su, T. P., Lien, T. C., Yang, C. Y., Su, Y. L., Wang, J. H., Tsai, S. L., \& Yin, J. C. (2007). Prevalence of psychiatric morbidity and psychological adaptation of the nurses in a structured SARS caring unit during outbreak: a prospective and periodic assessment study in Taiwan. Journal of Psychiatric Research,41(1-2), 119-130. https $/ /$ doi.org/10.1016/j.jpsychires.2005.12.006 
Sullivan G. C. (1989). Evaluating Antonovsky's Salutogenic Model for its adaptability to nursing. Journal of Advanced Nursing, 14(4),336-342. https:/doi.org/10.1111/j.1365-2648.1989.tb03421.X

Tang, S. T., Cheng, C. C., Lee, K. C., Chen, C. H., \& Liu, L. N. (2013). Mediating effects of sense of coherence on family caregivers' depressive distress while caring for terminally ill cancer patients. Cancer Nursing, 36(6), E25-E33.

https:/doi.org/10.1097/NCC.0b013e31826fc90d

Wiesmann, U., Dezutter, J., \& Hannich, H. J. (2014). Sense of coherence and pain experience in older age. International Psychogeriatrics, 26(1), 123-133.

https:/doi.org/10.1017/S1041610213001695 
SENSE OF COHERENCE \& FEAR OF COVID-19

Table 1.

Characteristics of the studied sample $(N=907)$

\begin{tabular}{|c|c|c|c|c|c|}
\hline & $M$ & $S D$ & Min & & $\operatorname{Max}$ \\
\hline Age (all participants) & 39.28 & 15.30 & 18.00 & & 102.00 \\
\hline Age (women) & 38.59 & 15.22 & 18.00 & & 101.00 \\
\hline \multirow[t]{2}{*}{ Age (men) } & 40.21 & 15.38 & 18.00 & & 102.00 \\
\hline & \multicolumn{2}{|c|}{$n$} & \multicolumn{3}{|c|}{$\%$} \\
\hline \multicolumn{6}{|l|}{ Gender } \\
\hline Women & \multicolumn{2}{|c|}{522} & \multicolumn{3}{|c|}{$57.55 \%$} \\
\hline Men & \multicolumn{2}{|c|}{385} & \multicolumn{3}{|c|}{$42.45 \%$} \\
\hline \multicolumn{6}{|l|}{ Education } \\
\hline Elementary School & \multicolumn{2}{|c|}{28} & \multicolumn{3}{|c|}{$3.09 \%$} \\
\hline Vocational & \multicolumn{2}{|c|}{65} & \multicolumn{3}{|c|}{$7.17 \%$} \\
\hline High School & \multicolumn{2}{|c|}{347} & \multicolumn{3}{|c|}{$38.26 \%$} \\
\hline University & \multicolumn{2}{|c|}{467} & \multicolumn{3}{|c|}{$51.49 \%$} \\
\hline \multicolumn{6}{|l|}{ Place of Residence } \\
\hline Village & \multicolumn{2}{|c|}{220} & \multicolumn{3}{|c|}{$24.26 \%$} \\
\hline Town & \multicolumn{2}{|c|}{410} & \multicolumn{3}{|c|}{$45.20 \%$} \\
\hline City & \multicolumn{2}{|c|}{277} & \multicolumn{3}{|c|}{$30.54 \%$} \\
\hline \multicolumn{6}{|l|}{ Professional Activity } \\
\hline Unemployed & \multicolumn{2}{|c|}{268} & \multicolumn{3}{|c|}{$29.55 \%$} \\
\hline Employed & \multicolumn{2}{|c|}{639} & \multicolumn{3}{|c|}{$70.45 \%$} \\
\hline
\end{tabular}


SENSE OF COHERENCE \& FEAR OF COVID-19

Table 2.

Results of the Pearson's $r$ correlation analysis $(N=907)$

\begin{tabular}{|c|c|c|c|c|c|c|c|}
\hline & & $M$ & $S D$ & 1. & 2. & 3. & 4. \\
\hline 1. & Stress & 20.57 & 5.87 & - & & & \\
\hline 2 . & Fear of COVID-19 & 21.41 & 5.84 & $.34 * * *$ & - & & \\
\hline & Sense of Coherence & 131.11 & 24.15 & $-.53 * * *$ & $-.14 * * *$ & - & \\
\hline & Life Satisfaction & 22.67 & 5.99 & $-.40 * * *$ & $-.10 * *$ & $.61 * * *$ & - \\
\hline
\end{tabular}

Note: $* * p<.01 ; * * * p<.001$ 
SENSE OF COHERENCE \& FEAR OF COVID-19

Table 3.

Detailed data of the results of the PROCESS Model 7 analysis $(N=907)$

\begin{tabular}{|c|c|c|c|c|c|c|c|}
\hline \multicolumn{8}{|c|}{ Mediation } \\
\hline Path & & & Symbol & $\beta$ & $S E$ & $L L C I$ & $U L C I$ \\
\hline $\bar{X}$ & $\rightarrow$ & $M$ & $\bar{a}$ & -.51 & .03 & -.573 & -.453 \\
\hline$M$ & $\rightarrow$ & Y & b & .53 & .03 & -.192 & -.071 \\
\hline$X(M)$ & $->$ & Y & $c^{\prime}$ & -.13 & .03 & .465 & .586 \\
\hline \multicolumn{8}{|c|}{ Indirect Effects } \\
\hline & & Low $W$ & $\mathrm{a}_{1} * \mathrm{~b}$ & -.32 & .03 & -.381 & -.262 \\
\hline & & Moderate $W$ & $a_{2} * b$ & -.27 & .02 & -.319 & -.226 \\
\hline & & High $W$ & $a_{3} * b$ & -.22 & .03 & -.275 & -.173 \\
\hline \multicolumn{8}{|c|}{ Moderation } \\
\hline Path & & & Symbol & $\beta$ & $S E$ & $L L C I$ & $U L C I$ \\
\hline$X$ & $\rightarrow$ & $M$ & $a_{1}$ & -.51 & .03 & -.573 & -.453 \\
\hline$W$ & $->$ & $M$ & $a_{2}$ & .06 & .03 & -.003 & .116 \\
\hline \multirow[t]{2}{*}{$X * W$} & $\rightarrow$ & $M$ & $\mathrm{a}_{3}$ & .10 & .02 & .039 & .146 \\
\hline & & IMM & - & .05 & .01 & .021 & .077 \\
\hline
\end{tabular}

Note: $\beta$ - standardized coefficient; $X$ - Stress; $W$-Fear of COVID- $19 ; M$ - Sense of Coherence; $Y$ - Life Satisfaction; IMM-Index of Moderated Mediation 
SENSE OF COHERENCE \& FEAR OF COVID-19

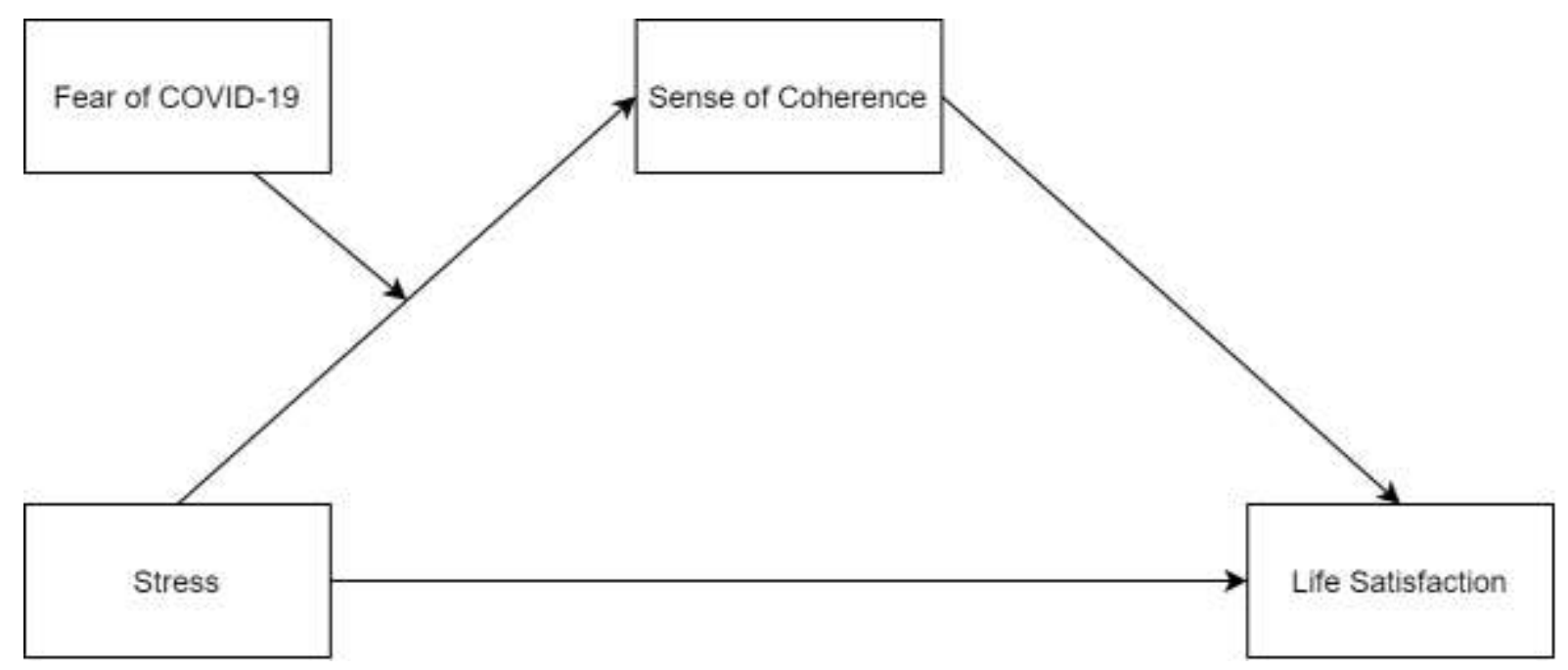

Figure 1. A proposed moderated mediation model. 
SENSE OF COHERENCE \& FEAR OF COVID-19

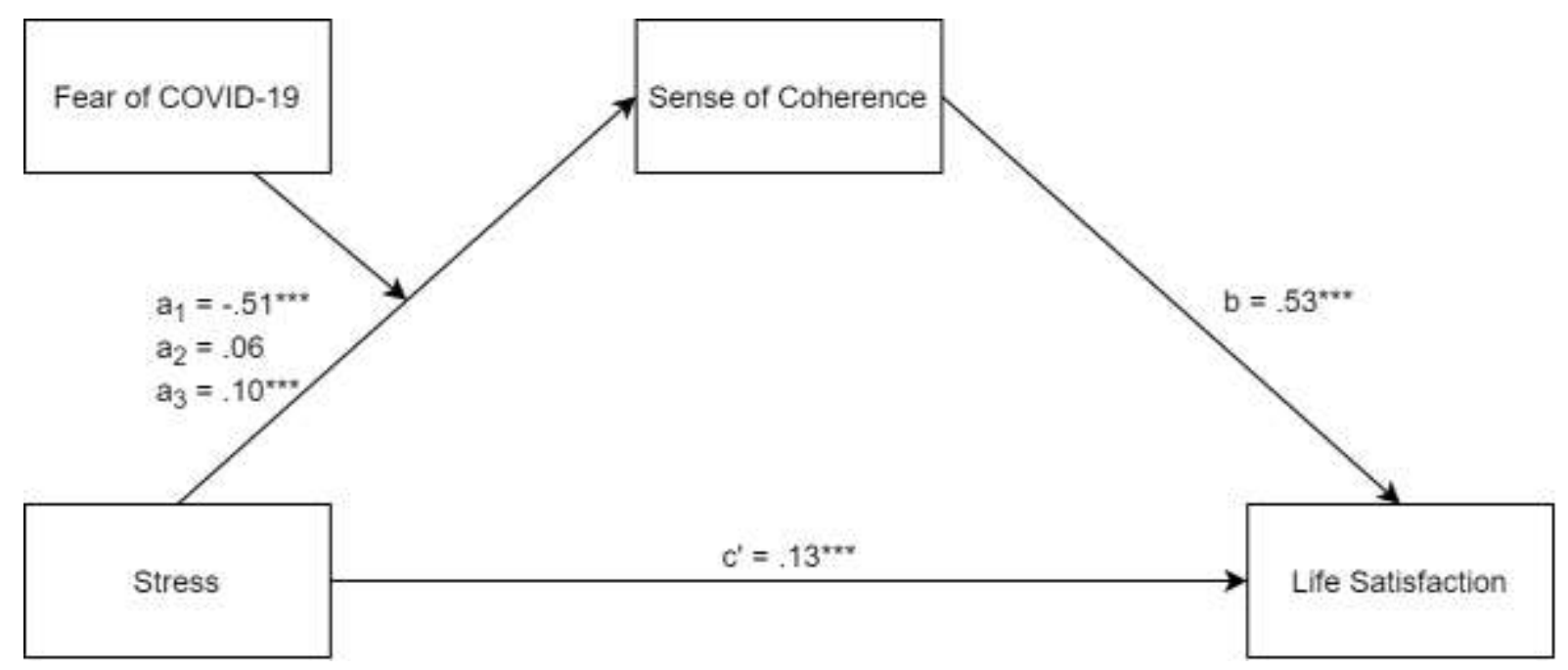

Figure 2. Results of the PROCESS Model 7 analysis 


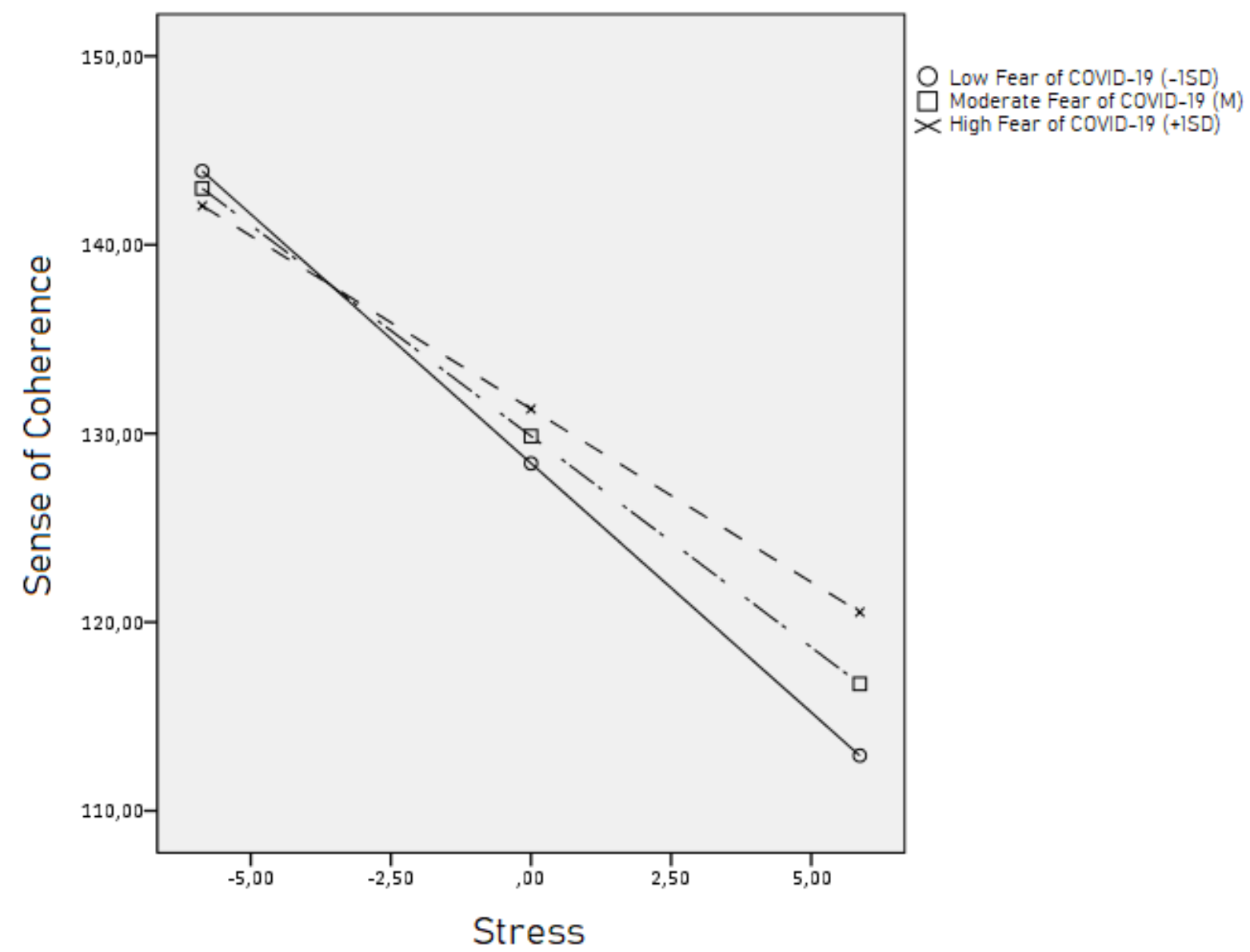

Figure 3. Interaction of stress and fear of COVID-19 as predictors of the sense of coherence 